\title{
Hubungan Obesitas dengan Kejadian Hipertensi di Wilayah Kerja Puskesmas Sidomulyo Rawat Inap
}

\author{
$\operatorname{Asyfah}^{1}$, Usraleli $^{2}$, Magdalena $^{3}$, Sakhnan $^{4}$, Melly $^{5}$ \\ 1,2,3,4,5 Poltekkes Kemenkes Riau, Jalan Melur No.103 Pekanbaru \\ Correspondence email: usraleli@pkr.ac.id, email: poltekkespekanbaru@yahoo.com
}

\begin{abstract}
Abstrak. Obesitas adalah suatu keadaan terjadinya penimbunan jaringan lemak tubuh secara berlebihan sehingga dapat menyebabkan masalah kesehatan yang serius seperti hipertensi. Obesitas dan hipertensi merupakan suatu penyakit multifaktorial. Ketidakseimbangan antara konsumsi kalori dengan kebutuhan energi yang disimpan dalam bentuk lemak yang menyebabkan jaringan lemak inaktif sehingga beban kerja jantung meningkat. Akibat dari obesitas, para penderita cenderung menderita penyakit kardiovaskuler. Tujuan : Untuk mengetahui hubungan obesitas dengan hipertensi di wilayah kerja Puskesmas Sidomulyo Rawat Inap. Metode : Penelitian ini bersifat Deskriptif Analitik, dilakukan pada 92 responden yang memiliki Body Mass Index (BMI) > 23.0. Pada penelitian ini, peneliti melakukan pengamatan mengenai bentuk fisik responden yang datang ke poli usila untuk memeriksakan kesehatannya, peneliti lalu meminta persetujuan apakah responden bersedia diperiksa tinggi dan berat badannya serta diperiksa tekanan darahnya. Hasil : Dari 18 responden yang mengalami pra obesitas, 17 responden (18,5\%) mengalami hipertensi dan 1 responden $(1,1 \%)$ diantaranya tidak mengalami hipertensi. Sedangkan dari 74 responden yang mengalami obesitas, 52 responden $(56,5 \%)$ mengalami hipertensi dan 22 responden $(23,9)$ diantaranya tidak mengalami hipertensi. Uji statistik yang digunakan adalah uji chi square $(\mathrm{p}=0,036)$. Kesimpulan : Ada hubungan yang signifikan antara Obesitas dengan Kejadian Hipertensi di Wilayah Kerja Puskesmas Sidomulyo Rawat Inap. Saran : Kesadaran akan pentingnya hidup sehat dengan berat badan ideal adalah kunci utama untuk memerangi obesitas dan mencegahnya sejak dini.
\end{abstract}

Kata Kunci: Body Mass Indeks (BMI); Lemak; Hipertensi; Kardiovaskular; Obesitas

Abstract. Obesity is a condition where excessive accumulation of body fat tissue can cause serious health problems such as hypertension. Obesity and hypertension is a multifactorial disease. Imbalance between consumption of calories and energy needs stored in the form of fat which causes inactive fat tissue so that increased work heart load. As a result of obesity, sufferers tend to suffer from cardiovascular disease. Objective: To determine the relationship of obesity to hypertension in the work area of Sidomulyo Community Health Center. Method: This study is descriptive analytical, conducted on 92 respondents who had a Body Mass Index (BMI)> 23.0. In this study, researchers conducted observations regarding the physical shape of the respondents who came to the elderly polyclinic to check their health, the researcher then asked for approval whether the respondent was willing to be examined for height and weight and blood pressure checked. Results: Of the 18 respondents who were pre-obese, 17 respondents (18.5\%) had hypertension and 1 respondent (1.1\%) had no hypertension. While from 74 respondents who were obese, 52 respondents $(56.5 \%)$ had hypertension and 22 respondents $(23.9 \%)$ had no hypertension. The statistical test used was the chi square test $(p=0.036)$. Conclusion: There is a significant relationship between Obesity and Hypertension in the Sidomulyo Community Health Center Working Area. Suggestion: Awareness of the importance of healthy living with an ideal body weight is the main key to fighting obesity and preventing it early.

Keywords: Body Fat; Body Mass Indeks (BMI); Hypertension; Kardiovaskular; Obesity

\section{PENDAHULUAN}

Menurut Departemen Kesehatan (Depkes) tahun 2016, Indonesia saat ini berada dalam masa transisi epidemiologi, dimana dalam upaya pembangunan di bidang kesehatan menghadapi beban ganda penyakit. Di satu pihak masih banyak penyakit infeksi/penyakit menular yang harus ditangani, di lain pihak semakin meningkatnya Penyakit Tidak Menular (PTM) yang segera membutuhkan perhatian serius bagi dunia. Hal tersebut dibuktikan dengan digunakannya PTM sebagai salah satu target yang harus dicapai dalam Sustainable Development Goals (SDGs). Pada tujuan SDGs ke-3, target 3.4 disebutkan "Pada tahun 2030 mengurangi hingga sepertiga angka kematian dini akibat penyakit tidak menular melalui pencegahan dan pengobatan serta meningkatkan kesehatan mental dan kesejahteraan". Indikator yang berkaitan dengan target 3.4 tersebut diantara lain prevalensi tekanan darah tinggi dan prevalensi obesitas pada penduduk umur $\geq 18$ tahun (Depkes, 2016).

PTM juga dikenal sebagai penyakit kronis, tidak dapat ditularkan dari orang ke orang. Mereka memiliki durasi panjang dan umumnya berkembang lambat. Faktor risiko PTM adalah suatu kondisi yang secara potensial berbahaya dan dapat memicu terjadinya PTM antara lain kurangnya aktivitas fisik, diet yang tidak sehat dan tidak seimbang, merokok, konsumsi alkohol, obesitas, dan hipertensi (Depkes, 2016). Beberapa contoh penyakit tidak menular seperti kanker, penyakit saluran pernapasan kronis, diabetes melitus dan penyakit kardiovaskular seperti hipertensi dan stroke. Menurut Kemenkes Republik Indonesia (RI), hipertensi merupakan salah satu faktor penting sebagai pemicu penyakit tidak menular seperti penyakit jantung, stroke 
dan lain-lain yang saat ini menjadi momok penyebab kematian tertinggi di dunia.

Menurut World Health Organization (WHO), hipertensi atau tekanan darah tinggi adalah peningkatan tekanan persisten pada pembuluh darah arteri, dimana tekanan darah sistolik sama dengan atau di atas 140 $\mathrm{mmHg}$ dan tekanan diastolik sama dengan atau di atas $90 \mathrm{mmHg}$. Hipertensi sering menyebabkan perubahan pada pembuluh darah yang dapat mengakibatkan semakin tingginya tekanan darah (Muttaqin, 2009). Tekanan darah merupakan salah satu parameter hemodinamika yang sederhana dan mudah dilakukan pengukurannya. Hemodinamika adalah suatu keadaan dimana tekanan darah dan aliran darah dapat mempertahankan perfusi atau pertukaran zat di jaringan tubuh (Muttaqin, 2009). Sekitar 90-95\% penderita hipertensi adalah hipertensi primer, yaitu dimulai sebagai proses labil (intermitten) pada individu pada akhir 30-an dan awal 50-an yang secara bertahap dan menetap (Widyanto dan Cecep, 2013).

Menurut WHO (2011) dalam Depkes (2016), menunjukkan 1 milyar orang di dunia menderita hipertensi, 2/3 diantaranya berada di negara berkembang yang berpenghasilan rendah sampai sedang. Prevalensi hipertensi akan terus meningkat tajam dan diprediksi pada tahun 2025 sebanyak $29 \%$ orang dewasa di seluruh dunia terkena hipertensi, dimana 333 juta berada di negara maju dan 639 juta sisanya berada di negara berkembang termasuk Indonesia. Hipertensi telah mengakibatkan kematian sekitar 8 juta orang setiap tahun, dimana 1,5 juta kematian terjadi di Asia Tenggara yang $1 / 3$ populasinya menderita hipertensi sehingga dapat menyebabkan peningkatan beban biaya kesehatan. Menurut WHO (2013), secara global penyakit kardiovaskular mengakibatkan 17 juta kematian setiap tahunnya, sedangkan komplikasi dari hipertensi mengakibatkan 9,4 juta kematian tiap tahunnya.

Hasil penelitian Sporadis di 15 Kabupaten/Kota di Indonesia, yang dilakukan oleh Felly PS, dkk (20112012) dari badan Litbangkes Kemenkes memberikan fenomena $17,7 \%$ oleh stroke dan 10,0\% kematian disebabkan oleh Ischaemic Heart Disease. Dua penyakit penyebab kematian teratas ini merupakan Soulmate Factor nya adalah hipertensi. Hipertensi merupakan penyakit kedua terbanyak yang dialami oleh pasien puskesmas di provinsi Riau yaitu sebanyak 48.685 kasus $(12,26 \%)$ (Depkes, 2016). Berdasarkan data dari Riskesdas (2013), menyatakan bahwa dari $25,8 \%$ orang yang menderita hipertensi hanya $1 / 3$ yang terdiagnosis, sisanya $2 / 3$ tidak terdiagnosis.

Berdasarkan data dari Depkes tahun 2015, hipertensi merupakan penyakit terbanyak diantara 10 penyakit kunjungan kasus PTM di Puskesmas sekota Pekanbaru yaitu sebanyak 36.476 kunjungan. Sedangkan menurut jenis kelamin, perempuan lebih banyak mengalami hipertensi dengan jumlah kunjungan 21.245 sedangkan laki-laki 15.231 kunjungan. Dari hasil studi pendahuluan yang dilakukan di Puskesmas Sidomulyo Rawat Inap didapatkan bahwa hipertensi merupakan kasus penyakit terbanyak pada tahun 2017 yaitu sebanyak 512 kasus dan meningkat pada tahun 2018 sebanyak 1050 kasus.

Kebanyakan masyarakat dengan hipertensi tidak mengetahui tanda dan gejala atau bahkan tidak merasakannya, akan tetapi secara umum gejala awal yang mungkin timbul dari hipertensi yaitu sakit kepala, perdarahan dari hidung, pusing, wajah kemerahan, dan kelelahan (Oktavianus dan Febriana, 2014). Menurut Dalimartha (2018) gejala-gejala seperti sakit kepala, mimisan, pusing atau migrain sering ditemukan sebagai gejala klinis hipertensi. Kadang-kadang hipertensi esensial berjalan tanpa gejala dan baru timbul gejala setelah terjadi komplikasi pada organ sasaran seperti pada ginjal, mata, otak dan jantung (Dalimartha, 2014).

Komplikasi yang dapat terjadi diantaranya dapat menyebabkan kompensasi jantung terhadap kerja keras berupa penebalan pada otot jantung kiri sehingga jantung akan semakin membutuhkan energi yang besar dan akan menimbulkan kekurangan oksigen dan berakibat rasa nyeri, kondisi ini jika dibiarkan terus menerus akan menyebabkan kegagalan jantung untuk memompa dan dapat menimbulkan kematian. Gangguan dari sistem saraf terjadi pada sistem retina (mata bagian dalam) dan sistem saraf pusat (otak), di dalam retina terdapat pembuluh-pembuluh darah tipis yang akan menjadi lebar saat terjadi hipertensi dan memungkinkan terjadinya pecah pembuluh darah yang akan menyebabkan gangguan pada organ penglihatan. Hipertensi yang berkepanjangan juga akan menyebabkan kerusakan dari pembuluh darah pada organ ginjal sehingga fungsi ginjal sebagai pembuang zat-zat racun bagi tubuh tidak berfungsi dengan baik. Sedangkan beberapa faktor yang dapat mempengaruhi terjadinya hipertensi yaitu usia, jenis kelamin, riwayat keluarga, merokok, kurang aktivitas fisik dan obesitas (Oktavianus dan Febriana, 2014).

Obesitas atau kegemukan bukan sekedar masalah kesehatan melainkan masalah kesadaran. Dulu kegemukan identik dengan kemakmuran, akan tetapi sekarang kegemukan merupakan suatu kelainan atau penyakit. Obesitas saat ini disebut sebagai The New World Syndrome, angka kejadiannya terus meningkat dimana-mana. Di seluruh dunia, kini dilaporkan ada lebih dari 1 milyar orang dewasa dengan berat badan lebih (gemuk), dan paling sedikit ada 300 juta orang yang masuk dalam kategori obesitas (BMI di atas 30). Di Amerika Serikat dan negara-negara maju di Eropa misalnya, hampir $2 / 3$ penduduk mengidap kegemukan. Sebuah penelitian yang dilakukan selama 15 tahun di Amerika Serikat memperlihatkan bahwa fast food yang sudah menjadi bagian dari kehidupan modern terbukti berkolerasi positif terhadap peningkatan obesitas. Orang yang terbiasa makan di restoran cepat saji, minimal 2 kali seminggu, umumnya memiliki bobot badan lebih 
berat sebanyak 4-5 kg daripada orang yang tidak makan di restoran cepat saji. Kentang yang digoreng terasa gurih, sehingga mendorong orang untuk memakan lebih banyak, melebihi kebutuhan tubuh (Redaksi Trubus).

Proporsi obesitas pada dewasa $>18$ tahun menurut Riskesdas (2018) menunjukkan peningkatan yang sangat signifikan dibandingkan tahun 2007 yaitu sebanyak 10,5\% masyarakat mengalami obesitas dan meningkat hingga 21,8\% pada tahun 2018. Berdasarkan data Riskesdas (2018) menyatakan bahwa provinsi Riau berada pada urutan ke 11 angka kejadian obesitas tertinggi dari 33 provinsi lainnya. Sedangkan di Kota Pekanbaru angka kejadian obesitas yaitu sebanyak 36,35\% (Dinkes, 2016). Berdasarkan data cakupan pemeriksaan obesitas di Puskesmas Sidomulyo Rawat Inap tahun 2017 jumlah penduduk yang mengalami obesitas di wilayah kerja Puskesmas Sidomulyo Rawat Inap adalah sebanyak 1095 penduduk, dimana perempuan lebih banyak mengalami obesitas dibandingkan laki-laki.

Obesitas merupakan suatu faktor utama yang mempengaruhi tekanan darah dan juga perkembangan hipertensi. Kurang lebih $46 \%$ pasien dengan indeks massa tubuh 27 adalah penderita hipertensi (Ardania, dkk 2012). Obesitas adalah ketidakseimbangan antara konsumsi kalori dengan kebutuhan enegi yang disimpan dalam bentuk lemak yang menyebabkan jaringan lemak inaktif sehingga beban kerja jantung meningkat (Oktavianus dan Febriana, 2014). Tekanan darah tinggi sama atau diatas 140/90 terdapat pada lebih dari sepertiga orang obesitas. Obesitas sendiri sudah dapat mengakibatkan kelemahan otot jantung atau cardiomyopathy, sehingga mengganggu daya pompa jantung (Husnah, 2012).

Salah satu upaya untuk mencegah hipertensi yaitu dengan mengetahui berat badan ideal agar bisa meminimalisir faktor risiko dengan menggunakan rumus BMI. BMI merupakan alat sederhana untuk memantau status gizi orang dewasa khususnya yang berkaitan dengan kekurangan dan kelebihan berat badan, dengan demikian mempertahankan berat badan normal memungkinkan seseorang dapat mencapai usia harapan hidup lebih panjang. Penggunaan rumus BMI hanya berlaku untuk orang dewasa di atas 18 tahun dan tidak dapat diterapkan pada bayi, anak, remaja, ibu hamil dan olahragawan (Supariasa, dkk, 2016).

Studi pendahuluan yang dilakukan peneliti pada 28-29 November 2018 di Perumahan Rajawali Sakti RW 15 pada 7 orang responden yang mempunyai berat badan berlebih didapatkan hasil 5 diantara 7 orang responden mengalami hipertensi. Hasil penelitian oleh Hasanah, dkk (2016) dengan judul "Hubungan Obesitas dengan Hipertensi pada Masyarakat RW 13 Dusun Mojosari Desa Ngenep Kecamatan Karangploso" pada 66 responden ditemukan bahwa ada hubungan yang sangat kuat antara obesitas dengan hipertensi pada masyarakat di wilayah RW 13 Dusun Mojosari Desa Ngenep
Kecamatan Karangploso. Penelitian yang dilakukan oleh Ole, dkk (2014) di Kecamatan Tomohon Tengah Kota Tomohon dengan judul "Hubungan antara Obesitas dan Gaya Hidup dengan Hipertensi pada Masyarakat di Kecamatan Tomohon Tengah Kota Tomohon" mendapatkan hasil yang bertentangan yaitu Obesitas tidak memiliki hubungan yang signifikan dengan hipertensi $(p=0,639>0,05)$.

Berdasarkan data tersebut di atas, terdapat pro dan kontra terhadap masalah hipertensi ini, dan juga apabila masalah ini tidak diteliti akan sulit untuk mengatasi masalah hipertensi yang sebenarnya bisa dicegah dengan cara pola hidup yang sehat, rajin melakukan aktivitas fisik serta menjaga berat badan ideal. Oleh karena itu, peneliti ingin mengetahui apakah ada hubungan obesitas terhadap kejadian hipertensi dengan melakukan pembuktian secara ilmiah melalui sebuah penelitian yang di fokuskan untuk mengetahui "Hubungan Obesitas dengan kejadian Hipertensi di Wilayah Kerja Puskesmas Sidomulyo Rawat Inap?"

\section{METODE}

Jenis penelitian yang digunakan dalam penelitian ini adalah Deskriptif Analitik dengan desain Cross Sectional. Penelitian ini akan dilaksanakan pada tanggal 23 Maret-4 April 2019 di wilayah kerja Puskesmas Sidomulyo Rawat Inap. Populasi dalam penelitian ini diambil dari data cakupan pemeriksaan obesitas di Puskesmas Sidomulyo Rawat Inap tahun 2017 yaitu sebanyak 1.095 kasus. Dalam menentukan sampel dalam penelitian ini, ditentukan tingkat kepercayaan 85\%, maka digunakan $15 \%(0,15 \%)$. Berdasarkan perhitungan sampel yang didapatkan jumlah sampel dalam penelitian ini adalah 92 orang menggunakan teknik purposive sampling. Variabel independennya adalah obesitas dan variabel dependennya adalah hipertensi. Pengumpulan data yang dilakukan peneliti adalah kuesioner. Pada penelitian ini analisis univariat digunakan untuk mendapatkan distibusi frekuensi dan persentase dari variabel obesitas dan hiprtensi dengan menggunakan metode statistik. Uji hipotesis yang digunakan adalah uji Chi Square untuk mengetahui hubungan obesitas dengan hipertensi.

\section{HASIL DAN PEMBAHASAN Analisa Univariat Obesitas}

Tabel 1. Distribusi Frekuensi Responden Berdasarkan Obesitas di Wilayah Kerja Puskesmas Sidomulyo Rawat Inap Tahun $2019(n=92)$

\begin{tabular}{cccc}
\hline No & Obesitas & Frekuensi (orang) & Persentase (\%) \\
\hline 1 & Pra Obesitas & 18 & 19,6 \\
2 & Obesitas & 74 & 80,4 \\
& Jumlah & 92 & 100 \\
\hline
\end{tabular}


Berdasarkan tabel 1 seluruh responden di Wilayah Kerja Puskesmas Sidomulyo Rawat Inap mengalami obesitas yaitu sebanyak 74 orang $(80,4 \%)$.

Kejadian Hipertensi
Tabel 2. Distribusi Frekuensi Responden Berdasarkan Kejadian Hipertensi di Wilayah Kerja Puskesmas Sidomulyo Rawat Inap Tahun $2019(\mathrm{n}=92)$

\begin{tabular}{cccc}
\hline \multirow{2}{*}{ No } & $\begin{array}{c}\text { Kejadian } \\
\text { Hipertensi }\end{array}$ & Frekuensi (orang) & Persentase (\%) \\
\hline 1 & Tidak & 23 & 25,0 \\
2 & Ya & 69 & 75,0 \\
& Jumlah & 92 & 100 \\
\hline
\end{tabular}

Berdasarkan tabel 2 mayoritas responden di Wilayah Kerja Puskesmas Sidomulyo Rawat Inap mengalami hipertensi yaitu sebanyak 69 orang (75\%).

\section{Analisa Bivariat}

Tabel 3. Hubungan Obesitas dengan Kejadian Hipertensi di Wilayah Kerja Puskesmas Sidomulyo Rawat Inap Tahun 2019 (n = 92)

\begin{tabular}{cccccccccc}
\hline \multirow{2}{*}{ No } & \multirow{4}{*}{ Hipertensi } & \multicolumn{2}{c}{ Pra Obesitas } & \multicolumn{2}{c}{ Obesitas } & \multicolumn{2}{c}{ Total } & p value \\
& & F & $\%$ & F & $\%$ & F & $\%$ & \\
\hline 1 & Ya & 17 & 18,5 & 52 & 56,5 & 69 & 75,0 & 0,036 \\
2 & Tidak & 1 & 1,1 & 22 & 23,9 & 23 & 25,0 & 100 \\
& Total & 18 & 19,6 & 74 & 80,4 & 92 & & \\
\hline
\end{tabular}

Tabel 3 menunjukkan hasil analisa mengenai hubungan obesitas dengan kejadian hipertensi di wilayah kerja puskesmas sidomulyo rawat inap. Dari 18 responden yang mengalami pra obesitas, 17 responden $(18,5 \%)$ mengalami hipertensi dan 1 responden $(1,1 \%)$ diantaranya tidak mengalami hipertensi. Sedangkan dari 74 responden yang mengalami obesitas, 52 respondn $(56,5 \%)$ mengalami hipertensi dan 22 responden $(23,9)$ diantaranya tidak mengalami hipertensi. Berdasarkan hasil uji statistik menggunakan uji chi square diperoleh nilai $p$ value sebesar 0,036 ( $p$ value $<0.05$ ) maka Ha diterima, jadi dapat disimpulkan bahwa ada hubungan yang signifikan antara Obesitas dengan Kejadian Hipertensi di Wilayah Kerja Puskesmas Sidomulyo Rawat Inap.

\section{Pembahasan}

Berdasarkan hasil penelitian dapat diketahui bahwa hasil uji statistik menggunakan uji chi square diperoleh nilai $p$ value sebesar 0,036 yakni $<0,05$. Berarti Ha diterima atau ada hubungan yang signifikan antara obesitas dengan kejadian hipertensi. Hasil penelitian ini sejalan dengan hasil penelitian Hasanah, dkk (2016) dengan judul "Hubungan Obesitas dengan Hipertensi pada Masyarakat RW 13 Dusun Mojosari Desa Ngenep Kecamatan Karangploso" pada 66 responden yang menyatakan bahwa ada hubungan yang sangat kuat antara obesitas dengan hipertensi pada masyarakat di wilayah RW 13 Dusun Mojosari Desa Ngenep Kecamatan Karangploso.

Proporsi obesitas pada dewasa $>18$ tahun menurut Riskesdas (2018) menunjukkan peningkatan yang sangat signifikan dibandingkan tahun 2007 yaitu sebanyak $10,5 \%$ masyarakat mengalami obesitas dan meningkat hingga 21,8\% pada tahun 2018. Obesitas merupakan suatu faktor utama yang mempengaruhi tekanan darah dan juga perkembangan hipertensi. Sampai saat ini hipertensi masih tetap menjadi masalah karena beberapa hal, antara lain meningkatnya prevalensi hipertensi, masih banyaknya pasien hipertensi yang belum mendapat pengobatan maupun yang sudah diobati tetapi tekanan darahnya belum mencapai target, serta adanya penyakit penyerta dan komplikasi yang dapat meningkatkan morbiditas dan mortalitas.

Obesitas merupakan ciri khas dari populasi hipertensi. Telah dibuktikan bahwa faktor ini mempunyai kaitkan erat dengan terjadinya hipertensi. Sekitar $60 \%$ penderita hipertensi mengalami overweight $>20 \%$ (Longo dkk, 2012). Kurang lebih $46 \%$ pasien dengan indeks massa tubuh $\geq 27$ adalah penderita hipertensi (Ardania, dkk 2012). Apabila orang tersebut mengalami obesitas, maka risiko untuk mengalami hipertensi juga meningkat dikarenakan lemak jenuh dan lemak trans yang masuk ke dalam tubuh secara terusmenerus dapat menyebabkan akumulasi lemak di dalam pembuluh darah. Akibatnya arteri menyempit dan perlu tekanan lebih besar untuk mengalirkan darah keseleruh tubuh.Walaupun belum dapat dijelaskan hubungan obesitas dengan hipertensi esensial, tetapi penyelidikan membuktikan bahwa daya pompa jantung dan sirkulasi volume darah penderita obesitas dengan hipertensi lebih tinggi dibandingkan dengan penderita hipertensi yang mempunyai berat badan normal (Dalimarta, 2008).

Menurut Jiang, dkk (2016) menyatakan bahwa, meskipun hubungan antara obesitas dan hipertensi sudah jelas pada anak dan orang dewasa, mekanisme dimana obesitas secara langsung menyebabkan hipertensi sedang diselidiki. Aktivasi sistem saraf simpatik, jumlah intraabdomen dan lemak intra-vaskular, retensi natrium yang menyebabkan peningkatan reabsorpsi ginjal, dan sistem 
renin-angiotensin dianggap memiliki fungsi penting dalam patogenesis dari hipertensi terkait obesitas.

Peneliti berasumsi, salah satu upaya untuk mencegah hipertensi yaitu dengan mengetahui berat badan ideal agar bisa meminimalisir faktor risiko penyebab masalah kesehatan serius yang dapat mengancam hidup yaitu hipertensi. Untuk mendapatkan berat badan ideal dapat dilakukan dengan cara menjaga pola makan, melakukan aktivitas fisik secara rutin. Olahraga isotonik, seperti bersepeda, joging, dan aerobik yang teratur dapat memperlancar peredaran darah sehingga dapat menurunkan tekanan darah. Pola makan yang sering mengkonsumsi makanan berlemak yang biasanya dilakukan oleh masyarakat suku minang dapat mempengaruhi berat badan dan tekanan darah. Makanan yang berlemak serta menggunakan bahan baku santan dianggap dapat memicu meningkatnya kadar kolesterol yang akan mempengaruhi tekanan darah karena bisa menyebabkan penumpukan plauqe di pembuluh darah yang akan meningkatkan beban kerja jantung sehingga tekanan darah meningkat. Ditambah lagi dengan kurangnya aktivitas fisik juga dapat mempengaruhi berat badan sehingga rentan terjadi obesitas akibat penumpukan lemak tubuh yang berlebihan, kedua faktor ini sangat erat hubungannya dengan insiden hipertensi terkait obesitas.

\section{SIMPULAN}

Kesimpulan dari penelitian yang telah dilakukan untuk mengetahui hubungan antara obesitas dengan kejadian hipertensi di Wilayah Kerja Puskesmas Sidomulyo Rawat Inap Tahun 2019 dengan jumlah responden sebanyak 92 orang dengan status berat badan berlebih adalah sebagai berikut: Mayoritas responden mengalami obesitas yaitu sebanyak 74 orang $(80,5 \%)$; Mayoritas responden mengalami hipertensi yaitu sebanyak 69 orang (75,0\%); Ada hubungan yang signifikan antara obesitas dengan hipertensi di wilayah kerja Puskesmas Sidomulyo Rawat Inap (hasil uji chi square diperoleh nilai $p$ sebesar $0,036<0,05$ ).

\section{DAFTAR PUSTAKA}

Ardania, S dan Prabowo, T. (2012). Hubungan Indeks Massa Tubuh dengan Tekanan Darah pada Masyarakat di Kelurahan Pakuncen Wirobrajan Yogyakarta. Thesis S2 pada STIKES 'Aisyiyah Yogyakarta: http://lib.unisayogya.ac.id.

Boediman, D. (2009). Sehat Bersama Gizi. Jakarta: CV Sagung Seto.

Dalimartha, dkk. (2008). Care Your Self, Hipertensi. Cet.1. Jakarta: Penebar Plus ${ }^{+}$

Depkes RI. (2017). Sebagian Besar Penderita Hipertensi tidak Menyadarinya. Jakarta:Depkes RI.http://depkes.go.id/article/view/17051800002/s ebagian-besar-penderita-hipertensi-tidakmenyadarinya.html
Depkes. (2016). Profil Kesehatan Provinsi Riau. Desember 5, 2018. http://www.depkes.go.id/resources/download/prof il/PROFIL_KES_PROVINSI_2016/04_Riau_201 $\underline{6 . p d f}$.

Dien, N. G., Mulyadi \& Rina, M. K. (2014). Hubungan Indeks Massa Tubuh (IMT) dengan Tekanan Darah pada Penderita Hipertensi di Poliklinik Hipertensi dan Nefrologi BLU RSUP PROF. DR. R. D. Kandau Manado. Jurnal Program Studi Ilmu Keperawatan Fakultas Kedokteran Universitas Sam Ratulangi Manado, 1.

Husnah. (2012). Penatalaksanaan Obesitas. Jurnal Kedokteran Syiah Kuala Vol. 12.

Irza, S. (2009). Analisis Faktor Risiko Hipertensi Pada Masyarakat Nagari Bungo Tanjung Sumatera Barat. Jurnal Universitas Sumatera Utara. Medan: Universitas Sumatera Utara

Jiang, dkk. (2016). Obesity and Hypertension (Review). Jurnal Departemen Kardiologi Xuzhou Central Hospital, 12, 2395-2399.

Kemenkes RI. (2018). Hipertensi The Silent Killer. http://www.pusdatin.kemkes.go.id/article/view/15 080300001/hipertensi-the-silent-killer.html

Longo DL, dkk. (2012). Hypertensive Vaskular Disease. Harrisons Principal Interne Medicine. $18^{\text {th }}$ ed. USA: The McGraw-Hill Companies, Inc.;

Muttaqin, A. (2009). Asuhan Keperawatan Klien dengan Gangguan Sistem Kardiovaskular. Jakarta: Salemba Medika.

My Healthy Life Kegemukan Pergi dan Tak Kembali. Desember 7, 2018.

https://books.google.co.id/books?id=YJK7DgAA QBAJ\&pg=PA115\&dq=my+healthy+life+kegem ukan+pergi\&hl=id\&sa=X\&ved=0ahUKEwjr38e3 g43fAhVNiXAKHehFAyEQ6AEILjAB\#v=onepa ge\&q=my\%20healthy\%20life $\% 20$ kegemukan $\% 20$ pergi\&f $=$ false

My Healthy Life. (2016). Obesitas Pergi dan Tak Kembali. Redaksi Trubus.

Notoadmodjo, S. (2012). Metodologi Penelitian Kesehatan. Ed. Rev. Jakarta: Rineka Cipta.

Novitaningtyas, T. (2014). Hubungan Karaktekteristik (Umur, Jenis Kelamin, Tingkat Pendidikan) dan Aktivitas Fisik dengan Tekanan Darah pada Lansia di Kelurahan Makamhaji Kecamatan Kartasura Kabupaten Sukoharjo. Surakarta: Universitas Muhammadiyah Surakarta

Oktavianus dan Febriana, S. (2014). Asuhan Keperawatan pada Sistem Kardiovaskuler Dewasa. Yogyakarta: Graha Ilmu.

Sari, T N, dkk. (2018). Hubungan Tingkat Stress dengan Hipertensi pada Pasien Rawat Jalan di Puskesmas Sidomulyo Rawat Inap Kota Pekanbaru Vol 1 No 3. Collaborative Medical Journal (CMJ). Pekanbaru: Universitas Abdurrab. 
Setiadi. (2013). Konsep dan Praktik Penulisan Riset Keperawatan. E.d 2, Cet.1. Yogyakarta: Graha Ilmu.

Soenanto, H. (2009). 100 Resep Sembuhkan Hipertensi, Asam Urat dan Obesitas. Jakarta: PT Elex Media Komputindo.

Sudargo, dkk. (2014). Pola Makan dan Obesitas. Yogyakarta: Gadjah Mada University Press.

Sudikno. (2016). Faktor Risiko Obesitas Sentral Pada Orang Dewasa Umur 25-65 Tahun Di Indonesia. Analisis Data Riset Kesehatan Dasar 2013. Bogor: Institut Teknologi Bandung (ITB)

Sudoyo, A, dkk. (2009). Buku Ajar Ilmu Penyakit Dalam Ed. 5. Jilid. 1. Jakarta: Interna Publishing.

Sugiyono. (2012). Statistik Nonparametris. Bandung: Ev. Alfabeta.

Sulastri, D, dkk. (2012). Hubungan Obesitas dengan Kejadian Hipertensi Pada Masyarakat Etnik Minangkabau di Kota Padang. Artikel Penelitian Bagian Gizi Fakultas Kedokteran Universitas Andalas. Padang: Universitas Andalas

Supariasa, D. N., Bachyar, B \& Ibnu, F. (2016). Penilaian Status Gizi (Ed. 2). Jakarta: Penerbit Buku Kedokteran EGC.

Triyantoi, E., Arif, S. P., \& Saryono. (2013). Buku Pedoman Kader Bagi Penderita Hipertensi.

Widyanto, F. C dan Cecep, T. (2013). Trend Disease "Trend Penyakit Saat Ini". Cet.1. Jakarta: CV Trans Info Media.

Yogiantoro, M. (2009). Hipertensi Essensial dalam Buku Ajar Ilmu Penyakit Dalam Edisi IV. Jakarta: Interna Publishing. 